\title{
New Concept of Delayed Open Reduction and Internal Fixation of Closed Recent Intra-articular Calcaneal Fractures
}

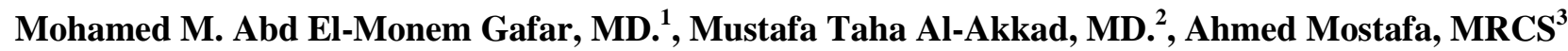 \\ Orthopaedic Surgery Department, Al-Jahra Hospital, Ministry of Health, Kuwait
}

\begin{abstract}
Aim: To evaluate proper timing for open reduction and internal fixation of closed recent intra-articular calcaneal fractures, and trying to establish a new concept of delayed surgery for these fractures in order to decrease post-operative wound complications, and so improving functional outcome. Design: Retrospective study. patients and Methods: 64 patients with 72 intra-articular calcaneal fractures, treated via open reduction using extensile lateral approach and internal fixation using plates and screws in our hospital; from February 2008 to December 2014. Results: Delayed, open reduction and internal fixation of closed recent intra-articular calcaneal fractures in our series showing reduction in post-operative wound complications; in our study the mean delaying in surgery, in uncomplicated group was 8.38 days post fracture. Conclusion: We recommend to delay open reduction and internal fixation, if indicated, for the treatment of closed recent intra-articular fractures, good appreciation, and management of the soft tissue condition pre-operatively, in order to reduce the post-operative wound complications, and therefore optimize the clinical outcome.
\end{abstract}

Keywords: fracture, calcaneus, surgery, delayed, timing

\section{Introduction}

The management of calcaneus fractures and their associated soft tissue injuries is a challenging task ${ }^{(1)}$. Being a cancellous bone, it may be deformed under compressive force during traumatic impact. Surgical restoration of the anatomy is difficult as reduction and stabilization are technically demanding. With the improvements in diagnosis and internal fixation techniques, surgical treatment has become a reality. Many authors claim better results with surgical treatment ${ }^{(2 / 3)}$. However, as the calcaneus being a subcutaneous bone, most part of calcaneum is covered with a thin layer of skin and subcutaneous tissue. Closed calcaneal fractures are usually associated with significant soft tissue injury caused by the initial trauma to its poor soft tissue coverage, which may result in a series of complications such as; post-operative skin flap necrosis or infection ${ }^{(4)}$.More injury, if added, to this area by surgical trauma may be associated with increase damage to this soft tissue envelope and devascularization of $\mathrm{it}^{(5)}$. So the postoperative wound complications remain a problem ${ }^{(6)}$. The most important predictors that influence the surgical outcome of these injuries are soft-tissue management ${ }^{(7)}$. Recognizing and managing soft tissue injury is the most important aspect of treating closed fractures. Simple skin contusion over a closed fracture can pose more complex therapeutic and prognostic problems than skin which has been broken by a fractured bone ${ }^{(8)}$.

Tscherne has proposed a classification of soft tissue damage based on the presence or absence of five lesions (abrasion, contusion, laceration, dissolving injury \& compartment syndrome) (table 1).
Table 1: Tscherne classification system

\begin{tabular}{|l|l|}
\hline Grade 0 & $\begin{array}{l}\text { Minimal soft tissue damage } \\
\text { Indirect injury to limb (torsion) } \\
\text { Simple fracture pattern }\end{array}$ \\
\hline Grade 1 & $\begin{array}{l}\text { Superficial abrasion or contusion } \\
\text { Mild fracture pattern }\end{array}$ \\
\hline Grade 2 & $\begin{array}{l}\text { Deep abrasion } \\
\text { Skin or muscle contusion } \\
\text { Severe fracture pattern } \\
\text { Direct trauma to limb }\end{array}$ \\
\hline Grade 3 & $\begin{array}{l}\text { Extensive skin contusion or crush injury } \\
\text { Severe damage to underlying muscle } \\
\text { Compartment syndrome } \\
\text { Subcutaneous avulsion }\end{array}$ \\
\hline
\end{tabular}

Swelling \& fracture blisters are additional two important soft-tissue lesions not included in Tscherne classification. Swelling can be assessed and graded clinically, as loss of skin wrinkles and palpable landmarks (wrinkle sign) suggests moderate to severe swelling (figure1).

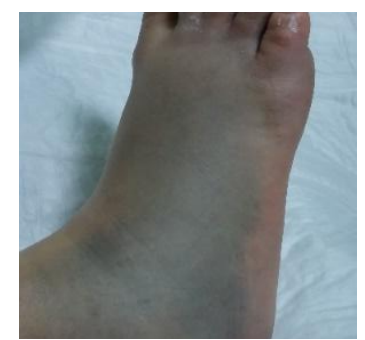

Figure 1: Wrinkle sign; suggests moderate to severe swelling.

Loss or delay of capillary refill and intraoperativeblanching of the skin or loss of capillary refill with approximation of wound edges suggests severe swelling ${ }^{(9)}$. Fracture blisters are classified into: (1) Clear fluid-filled blisters which are probably not a reason to delay or alter surgical strategy and (2) Blood-filled blisters represent a deeper injury with a higher risk of poor healing and direct incision through them should be avoided. In the presence of blood-filled blisters 


\section{International Journal of Science and Research (IJSR) \\ ISSN (Online): 2319-7064}

Index Copernicus Value (2013): 6.14 | Impact Factor (2015): 6.391

and or severe swelling it is necessary to wait for the reepithelialization of blisters and subsidence of skin swelling to avoid the significantly higher rate of complications. The disadvantage of delayed surgery is that a satisfactory reduction may become extremely difficult ${ }^{(9 / 15)}$. Posttraumatic soft tissue injuries may classify into three grades including Tscherne criteria plus presence or absence of swelling and blisters (table2).

Table 2: Grades of post-traumatic soft tissue injury

\begin{tabular}{|c|c|c|c|}
\hline \multirow{2}{*}{$\begin{array}{c}\text { Soft tissue } \\
\text { injury } \\
\text { Grade }\end{array}$} & \multicolumn{3}{|c|}{ Presence of one or more of the following: } \\
\cline { 2 - 4 } & Tscherne & Swelling & Blisters \\
\hline Grade 0 & 0 & No & No \\
\hline Grade 1 & $\begin{array}{c}\text { Superficial } \\
\text { abrasion }\end{array}$ & $\begin{array}{c}\text { Mild: Preservation of } \\
\text { skin wrinkles and } \\
\text { palpable landmarks }\end{array}$ & Clear \\
\hline Grade 2 & $\begin{array}{c}\text { Deep, } \\
\text { contaminated } \\
\text { abrasion with } \\
\text { local } \\
\text { contusion }\end{array}$ & $\begin{array}{c}\text { Moderate: Loss of } \\
\text { skin wrinkles \& } \\
\text { palpable landmarks } \\
\text { (wrinkle sign) }\end{array}$ & $\begin{array}{c}\text { Hemorrhagic } \\
\text { localized }\end{array}$ \\
\hline Grade 3 & $\begin{array}{c}\text { Extensive skin } \\
\text { contusion or } \\
\text { crushing or } \\
\text { muscle } \\
\text { destruction }\end{array}$ & $\begin{array}{c}\text { Severe: loss or delay } \\
\text { of capillary refill, } \\
\text { either preoperatively } \\
\text { or intraoperatively, } \\
\text { with approximation } \\
\text { of the wound edges }\end{array}$ & \\
\hline
\end{tabular}

The incidence of post-operative wound complications varies from $0 \%$ to $32.8 \% \%^{(3,6)}$. So the purpose of this study was firstly, to find the incidence of post-operative wound complications after open reduction and internal fixation, as a treatment of closed recent intra-articular calcaneal fractures in our series; and secondary, to identify a proper timing for this treatment, and trying to establish a new concept of delayed surgery for these fractures surgical treatment, in order to decrease post-operative wound complications, and so improving functional outcome.

\section{Patients and methods:}

All data were collected retrospectively; from our study which conducted from February 2008 to December 2014at orthopaedic department in our hospital; we studied 64 patients (with 72 intra-articular calcaneal fractures), all patients were adults, 54 males and 10 females with a ratio of $5.4: 1$. The mean age of the patients was 35.66 years with a range 16-60 years (figure 2). 32 patients had right sided fracture, 24 had left sided fracture, and 8 had bilateral fractures. Mechanism of injury mostly was falling from a height in $50(78.1 \%)$ cases. Looking at the occupation of the patients, most $53(82.8 \%)$ were blue collar workers, there were $5(7.8 \%)$ white collar, and $6(9.4 \%)$ were unemployed. The fracture classified according to Essex-Lopresti and Sander and all fractures were of closed type. All patients were primary; clinically and radiologically assessed. The duration of delaying from injury till surgery ranged from 1: 19 days with a mean of 7.4 days, and can be distributed as shown in (table 3 ) and (figure 3 ).
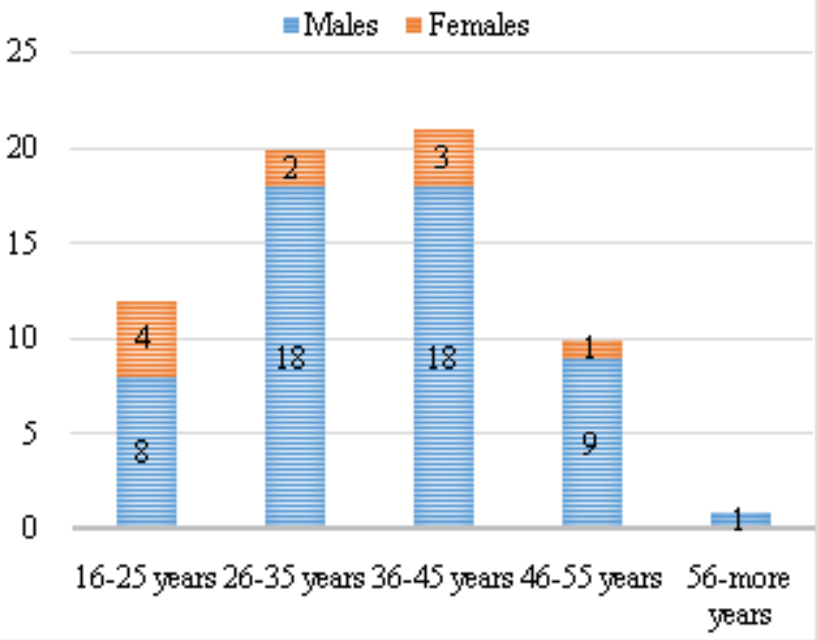

Figure 2: Distribution of patients into age groups in correlation with the sex in our series

\begin{tabular}{|c|c|c|}
\hline Time of surgery. (Days). & No. (Patients). & $\%$. \\
\hline $1^{\text {st }} \cdot-7^{\text {th }}$. & 37 & 57.8 \\
\hline $8^{\text {th }} \cdot 114^{\text {th }}$. & 22 & 34.4 \\
\hline $15^{\text {th }} \cdot 21^{\text {st }}$. & 5 & 7.8 \\
\hline Total. & 64 & 100 \\
\hline
\end{tabular}

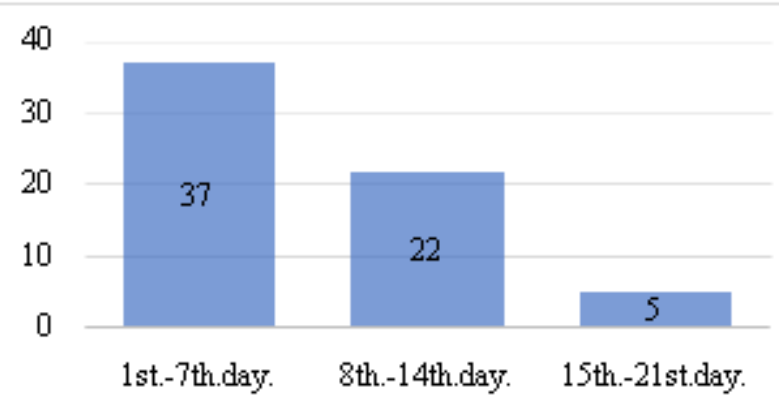

Table (3) \&Figure (3):The duration of delaying from injury till surgery in our series.

All were treated via open anatomical reduction using extended lateral approach. A tourniquet was used in all cases. The fractures were rigidly internally fixed; using plates and screws surgical wound closed witha deep haemovac drain is placed exiting proximally in line with the vertical limb of the incision. The tourniquet is deflated and sterile dressings are placed, followed by a bulky Jones dressing.

The injured limb kept elevated, an elastic compression stocking applied, analgesia given according to the patient tolerance to pain, and intra-venous antibiotics were administrated for 72 hours postoperatively followed by prophylactic oral antibiotics for one week more. The haemovac drain removed after 48 hours post operatively. All patients were encouraged for early mobilization started on $2^{\text {nd }}$ day post-operatively. The anticoagulant stopped once the patient started mobilization out of the bed. The patient usually discharged from the hospital after being steady mobilized out of bed, usually on 3rd. day post-operatively. The sutures are removed once the incision is fully sealed and dry, typically at 2-3 weeks; the sutures should not be removed, however, until the wound is fully healed. All cases 


\section{International Journal of Science and Research (IJSR) \\ ISSN (Online): 2319-7064}

Index Copernicus Value (2013): 6.14 | Impact Factor (2015): 6.391

were strictly followed up both clinically and radiologically range of 4-45 months, with mean follow up period of 11.9 months.

\section{Results}

The criteria used to describe wound complications were as follow; acute infection was defined by using clinical criteria such as inflammatory signs or persistent drainage with or without positive culture results that resolved with local care. Beyond 2 weeks, infection was defined as a clinical situation requiring antibiotics; wound edges necrosis and wound dehiscence. In our series wound complications following surgical treatment of 72 closed intra-articular calcaeal fractures, occurred in 19 (26.4\%) fractures (table 4).

Table 4: wound complications following surgical treatment of 72 closed intra-articular calcaeal fractures.

\begin{tabular}{|c|c|c|}
\hline Type of early complication & $\begin{array}{c}\text { No. of } \\
\text { fractures }\end{array}$ & $\%$ \\
\hline Wound edges necrosis and wound dehiscence. & 13 & 18.1 \\
\hline Superficial infection. & 6 & 8.3 \\
\hline Total. & 19 & 26.4 \\
\hline
\end{tabular}

- Wound edges necrosis and wound dehiscence:

Occurred in $13(18.1 \%)$ fractures; all treated by local care of the wound and regular dressing; except 2 fractures needed debridement and secondary closure.

\section{- Superficial infection:}

In our series this occurred in $6(8.3 \%)$ fractures; 3 are treated by local care, and 3 required antibiotics, one of them need debridement and secondary closure.

\section{Statistical analysis:}

For the purpose of statistical analysis, the fractures are divided, according to post-operative wound complications; into complicated and uncomplicated groups, and timing of surgery was studied in relation to this, to identify the surgical proper timing (table5).

Statistical analysis was performed using Statistical Package for Social Services software SPSS ${ }^{\mathrm{TM}}$ program.

Table 5: The statistical analysis of surgical timing in relation to wound complications following surgical treatment of closed recent intra-articular calcaneal fractures

\begin{tabular}{|c|c|c|c|}
\hline & Fractures & \multicolumn{2}{|c|}{ Surgical timing } \\
\cline { 3 - 4 } & No. & $\begin{array}{c}\text { Range } \\
\text { (days) }\end{array}$ & $\begin{array}{c}\text { Mean } \\
\text { (days) }\end{array}$ \\
\hline Complicated group. & 19 & $1-12$ & 4.84 \\
\hline Uncomplicated group. & 53 & $1-19$ & 8.38 \\
\hline
\end{tabular}

\section{Discussion}

Although the surgical treatment of the calcaneal fractures seems to improve the outcome, the wound complications rate after surgery and internal fixation remains high. Initial injuries of the hindfoot can cause serious damage to both soft tissues and bone in this area with an insufficient vascular structure. Failing to appreciate the soft tissue condition pre-operatively will invariably complicate the post-operative wound with; infection, dehiscence, or wound edge necrosis. Minor complications in the soft tissues increase the rate of major complications; therefore, delicate handling of the soft tissues and proper timing of surgery are very important for outcome improving ${ }^{(16 / 17)}$.

To reduce the post-operative complications in these injuries, and improve the clinical outcome, we should meticulously appreciate the post traumatic soft tissue injury preoperatively, and properly managing it on basis like the Damage Control Orthopaedic (DCO) approach to the injured limb, which requires fixing local metabolic disturbances, ensuring adequate perfusion, and recovering of the soft tissue envelop prior to the surgery. This is what is known as a Limited Limb Damage Control Approach, which can be applied to complex periarticular / articular injuries ${ }^{\left(1^{8}\right)}$

In our study; out of 72 displaced intra-articular calcaneal fractures, it was $26.4 \%$ (19 fractures); including wound edges necrosis and wound dehiscence in $18.1 \%$ (13 fractures), and wound superficial infection in $8.3 \%$ (6 fractures).

In comparable to other reported studies, Palarick. ${ }^{(19)}$ reported seven infections in 28 fractures treated surgically $(25 \%)$. Chan et al. ${ }^{(20)}$ reported three infections in 31 patients $(9.6 \%)$. Zwipp et al. ${ }^{(21)}$ reported a wound edge necrosis rate of $8.3 \%$ and haematoma rate of $2.5 \%$ in 157 patients. Be'zes et al. ${ }^{(2)}$ reported an infection rate of $5 \%$ and skin necrosis rate of $8 \%$ in 120 fractures. Stromsoe et al. ${ }^{(22)}$ recorded superficial infection and skin necrosis in 12 of 46 fractures $(28.2 \%)$.

From The statistical analysis of surgical timingin relation to wound complications following surgical treatment of closed recent intra-articular calcaneal fractures (table 5); we can find: post-operative surgical wound Complications were decreasing with appropriate delay surgical intervention ${ }^{\left(23 / 2^{4)}\right.}$ until wrinkling of the skin reappears andre-epithelialization of blisters prior to afflicting a second assault on the soft tissue envelope. For all calcaneal fractures requiring surgical intervention; we suggest a treatment protocol of two stage; firstly, the leg must be elevated, close observation of distal circulation, cold compresses, and anti-edematous medications started on admission. This stage delayed surgical intervention which is the second stage, allowing the soft tissue envelope to recover and swelling to subside to a large extent thereby promoting better integument closure and wound healing following surgery. In our study the appropriate delaying in surgery mean was 8.38 days post fracture.

\section{Conclusion}

Despite developments in the surgical treatment of a fractured calcaneum, wound complications following operative fixation still remain a problem. Based on our result, it appears that the high rates of post-operative wound complications after open reduction and internal fixation of closed recent calcaneal fractures may be due to attempts for early fixation through swollen, compromised injured soft tissues. When a staged procedure is performed with initial restoration and stabilization of the closed injured soft tissue, by elevation, coldfomentation, anti-edematous drugs, and 


\section{International Journal of Science and Research (IJSR) \\ ISSN (Online): 2319-7064}

Index Copernicus Value (2013): 6.14 | Impact Factor (2015): 6.391

observation, and once soft tissue swelling has significantly diminished, and wrinkling of the skin reappears andreepithelialization of blisters, second stage of anatomic reduction and internal fixation can then be performed electively. This two-staged delayed approach offers acceptable results for the treatment of closed recent intraarticular calcaneal fractures. These results compare favorably with those of early open reduction and internal fixation for these fractures. The major advantages include; decreased post-operative wound complications, improved healing, reduced hospital stay and so improved functional outcome. So, we suggested this two-staged delayed approach, in order to reduce the post-operative wound complications after open reduction and internal fixation of closed recent intra-articular calcaneal fractures, and therefore optimize the clinical outcome. Our results highlights that; Proper timing of the surgery has been pointed out as important for the final outcome, we suggest to postpone surgery till the soft tissue recovered, and permitted surgery. In our study the appropriate delaying in surgery mean was 8.38 days post fracture; Respecting the soft tissues in management of closed recent intra-articular calcaneal fractures decrease the devastating post-operative complications.

\section{References}

[1] Sanders R, Fortin P, DiPasquale T, Walling A. (1993): Operative treatment in 120 displaced intraarticular calcaneal fractures. Results using a prognostic computed tomography scan classification. ClinOrthop 290:87-95, 1993.

[2] Be'zes H, Massart P., Delvaux D., Fourquet JP., Taz F.: The operative treatment of intraarticular calcaneal fractures.ClinicalOrthopaedics and Related Research, Volume 290, 1993, pp. 55-59, View Record in ScopusCiting articles (122).

[3] Leung KS, Yuen KM, Chan WS.: Operative treatment of displaced intra-articular fractures of the calcaneum. Medium-term results. J. Bone Joint Surgery, Volume 75-B, 1993, pp. 196-201, View Record in ScopusCiting articles (112).

[4] Tang X, Tang PF, Wang MY, Lü DC, Liu MZ, et al. (2012) Pilon fractures: a new classification and therapeutic strategies. Chin Med J (Engl) 125: 2487-2492.

[5] Thornes BS, Collin AL, Timlin M, Corrigan J. (2002): Outcome of calcaneal fractures treated operatively and non-operatively. The effect of litigation on outcomes. Ir J Med Sci. 2002; 171: 155-7.

[6] Folk JW, Starr AJ, Early JS: Early wound complications of operative treatment of calcaneus fractures: Analysis of 190 fractures; J Orthop Trauma 1999; 13:369-372.

[7] Sirkin M, Sanders R, DiPasquale T, Herscovici D Jr (1999) A staged protocol for soft tissue management in the treatment of complex pilon fractures. J Orthop Trauma 13: 78-84.

[8] Robinson CM, McLauchlan GJ, McLean IP, Court-Brown CM (1995) Distal metaphyseal fractures of the tibia with minimal involvement of the ankle. Classification and treatment by locked intramedullary nailing. J Bone Joint Surg Br 77: 781-787.
[9] Tscherne H, Lobenhoffer P (1993) Tibial plateau fractures. Management and expected results. ClinOrthopRelat Res: 87-100.

[10] Tull F, Borrelli J Jr (2003) Soft-tissue injury associated with closed fractures: evaluation and management. J Am AcadOrthopSurg 11: 431-438.

[11] Giordano CP, Koval KJ (1995) Treatment of fracture blisters: a prospective study of 53 cases. J Orthop Trauma 9: 171-176.

[12] Thordarson DB (2000) Complications after treatment of tibialpilon fractures: prevention and management strategies. J Am AcadOrthopSurg 8: 253-265.

[13] Tarkin IS, Clare MP, Marcantonio A, Pape HC (2008) An update on the management of high-energy pilon fractures. Injury 39: 142-154.

[14] Brumback RJ, McGarvey WC (1995) Fractures of the tibial plafond. Evolving treatment concepts for the pilon fracture. OrthopClin North Am 26: 273-285.

[15] Bhattacharyya T, Crichlow R, Gobezie R, Kim E, Vrahas MS (2006) Complications associated with the posterolateral approach for pilon fractures. J Orthop Trauma 20: 104-107.

[16] Mast JW, Spiegel PG, Pappas JN (1988) Fractures of the tibialpilon. ClinOrthopRelat Res: 68-82.

[17] Rammelt S, Endres T, Grass R, Zwipp H (2004) The role of external fixation in acute ankle trauma. Foot Ankle Clin 9: 455-474, vii-viii.

[18] Nanchahal J, Nayagam S, Khan U, Moran C, Barrett S, Sanderson F, et al. Standards for the management of open fractures of the lower limb: a short guide [pamphlet]. London: British Association of Plastic Reconstructive and Aesthetic Surgeons and British Orthopaedic Association; 2009.

[19] Palarick J.: Surgical treatment of selected calcaneal fractures. RozhlChir., Volume 76, Issue 5, 1997, pp. 231238.

[20] Chan S, Ip FK.: Open reduction and internal fixation for displaced intra-articular fractures of the oscalcis. Injury, Volume 26, Issue 2, 1995, pp. 111-115. Article | PDF (743 K) | View Record in Scopus.

[21] Zwipp H, Tscherne H, Thermann H, Weber T. Osteosynthesis of displaced intraarticular fractures of the calcaneus. Results in 123 cases. Clinical Orthopaedics and Related Research, Volume 290, 1993, pp. 76-86. View Record in Scopus Citing articles (232).

[22] Stromsoe K., Mork E, Hem ES: Open reduction and internal fixation in 46 displaced intraarticular calcaneal fractures. Injury, Volume 29, Issue 4, 1998, pp. 313-316. Article | PDF $(557 \mathrm{~K})$ | View Record in Scopus Citing articles (12).

[23] Al-Mudhaffar M, Prasad CVR, Mofidi A: Wound complica- tions following operative fixation of calcanel fractures. Injury 2000; 31:461-464.

[24] Zwipp H, Tscherne $H$, Thermann $H$, Weber T: Osteosynthesis of displaced intrarticular fractures of the calcaneus. Clin Or- thop 1993 ; (290):76-86.

\section{Author Profile}

Mohamed M. Abd El-Monem Gafar is MD.Orthopaedic, Assistant Fellow, and Orthopaedic Consultant, Orthopaedic Surgery Dept., Banha Teaching Hospital, Egypt. Orthopaedic Surgery Dept., Al-Jahra Hospital, Ministry of Health, Kuwait. 